\title{
La importancia de las coaliciones en las políticas sobre drogas. Algunas consideraciones derivadas de la teoría y de la observación.
}

\section{The role of coalitions in drug policy. Some theoretical and observational considerations.}

\author{
| AMBROS UCHTENHAGEN
}

Research Institute for Public Health and Addiction. Zurich. Switzerland.

\section{RESUMEN}

Las sociedades organizadas democráticamente están obligadas a encontrar la manera de proceder en caso de necesitar una reformulación de las estrategias frente a los nuevos avances sociales y tecnológicos, especialmente cuando hay preferencias e intereses controvertidos. Los cambios en politica de drogas son un ejemplo excelente para discutir el problema y el proceso de formación de coaliciones para encontrar respuestas aceptables a los nuevos desafios. La moderna teoria sociológica ha desarrollado conceptos y herramientas para la descripción y el análisis de tales procesos. El estudio de casos concretos referentes a ciudades suizas pueden servirnos para la discusión avanzada de conceptos teóricos. El seguimiento observacional de la formación de coaliciones en la ciudad de Zurich, ayuda a ilustrar los elementos inherentes, los problemas, y los resultados. Un análisis más detallado del proceso centrado en las fases iniciales y el desarrollo subsiguiente de diversas coaliciones formales e informales introduce la importancia de los objetivos compartidos y la necesidad de actividades concertadas. No se dispuso al principio de un concepto de política clara y un plan de acción coherente, pero resultó ser un paso importante en la consolidación de lo que fue un comienzo no sistematizado. Lo que se inició a nivel local y llego a ser una nueva política nacional, dejo de ser un enfrentamiento constante entre dos ideologías - la reducción de daños contra la prohibición estricta -, para convertirse en el comienzo de una nueva forma de pensar acerca de cómo los elementos de las diferentes estrategias podrian combinarse con éxito en la búsqueda de un objetivo concreto a compartir. Estas observaciones pueden ser consideradas en futuros desarrollos teóricos y consideración sobre politicas.

Palabras clave: política de drogas, estudio de caso, creación de coaliciones, aprendizaje social, teoría de la acción en red.

\section{ABSTRACT}

Democratically organised societies have to find ways how to proceed when in need of a reformulation of strategies in face of new societal and technological developments, especially in dealing with controversial preferences and interests. The area of drug policy change presents an excellent example for discussing the problem and the process of coalition building for finding acceptable answers to new challenges. Modern sociological theory has developed concepts and tools for a description and analysis of such processes. Some concrete case studies from Swiss cities are available as a basis for advanced discussion of theoretical concepts. The observational description of the coalition building in the city of Zurich helps to illustrate the inherent elements, problems and outcomes; a more detailed process analysis focuses on the initial phases and further development of the various formal and informal coalitions, introducing the importance of shared objectives for action and the need for concerted activities. A clear policy concept and a consistent action plan were not available at first, but they proved to be an important step in the consolidation of what was a non-systematic beginning. What started at local level and led to a new national policy was not so much a continued clash between two ideologies - harm reduction versus strict prohibition -, but was the beginning of a new thinking about how the various policy elements could successfully work together in the pursuit of a shared concrete objective. These observations may be considered in further theory development and policy considerations.

Key words: urban drug policy, case study, coalition building, societal learning, actor network theory. 


\section{THE PROBLEM: HOW TO MANAGE DRUG POLICY CHANGE}

ike many other phenomena in modern societies, the use and abuse of psychotropic substances and its social and health concomitants are intrinsically linked to life conditions and lifestyles of people and to changes thereof (WHO 2001). Accordingly, the societal responses in terms of drug policy are open to change as well. The constant questions are: what is expected from drug policy? How are the expected outcomes to be achieved? What should be changed and hopefully - be improved in existing policies? Which other policy areas have to be considered to influence drug policy?

Authoritarian systems have the power to answer these questions and to implement the changes if considered to be necessary. Western democracies have to deal with a more complicated process: raising awareness for the need of change, prioritising potential objectives of change, screening potential options for change, and especially working for the acceptability and implementation of proposed change. An important element is the identification of barriers and obstacles, and finding eventual ways how to deal with them; democracy is about having choices and to engage in a consensus building process.

\section{USEFUL NETWORK THEORIES AND MODELS}

Sociological theory and studies have focused increasingly on how political, cultural and technological innovation and change happens. A common denominator of such approaches is a system-based view of societies, with subsystems and networks of actors initiating and supporting innovation, rather than single 'heroic' innovators and actors. Prominent examples are the advocacy coalition framework (Sabatier, 1998), social network theory (Freeman, 2006), normalization process theory (May, Mair, Finch, MacFarlane, Dowrick, Treweek et al. 2009), and diffusion of innovations theory (Wejnert, 2002; Rogers, 2003). A more general perspective offers the theory of societal learning (Waddell, 2005). One step further goes the actornetwork theory ANT which includes non-human factors into the network analysis (Law \& Hassard 1999, Latour, 2005). ANT has been applied, among others, to the health field. It has also met substantial criticism; it is argued that research based on ANT perspectives remains entirely descriptive and fails to provide explanations for social processes. ANT is much more interested in exploring how actor-networks get formed, hold themselves together, or fall apart. A further step is the development of tools for mapping out and interpreting scientific controversies in complex matters, in order to facilitate orientation and coalition forming (Callon, Lascoumes \& Barthe, 2009).

\section{ANALYSIS OF DRUG POLICY NETWORKS IN SWISS CITIES}

Case studies illustrating the process of coalition building for drug policy change have been made in a number of Swiss cities.
Systematic analysis in 4 cities (Bern, Chur, St. Gall \& Zurich) built first on the empirical identification of institutions, actors, competences and procedures which are relevant in the drug policy area, followed by an analysis of the specific interaction and dependence patterns. Two separate networks are in focus: the policy network and the decision-making network. Moving beyond ANT, specific hypotheses on determinants are tested. As a result, the independent variables shaping the policy network are: the size of the city, the size of the local drug problems (including the HIV epidemic and the correspondent media interest), the dominant political parties and the administrative structure. On the other side, the decision-making network is mainly determined by the structure and characteristics of the policy network, and less than expected on the politically and administratively preferred types of regulatory measures. The role of coalition building is well demonstrated (Serduelt, 2000).

Another analysis was using the advocacy coalition framework (ACF) (Sabatier, 1998), complemented by social movement theory and the two concepts of mobilizing structures and political opportunity structures (Kübler, 1999, 2000, 2001). The ACF understands the policy process as a competition between coalitions of actors who advocate beliefs about policy problems and solutions. In the case of Swiss drug policy, this means a competition between a prohibitionist and a harm-reduction coalition. The latter developed the belief that measures to prevent blood borne infections must override the inefficient belief in preventing drug use in an abstinence-only perspective not only for the sake of users, but in order to protect the general population as well. The implementation of the harm reduction policy had to be tailored, in a second step, to the needs of public order, reducing public nuisance. The concept of "Stadtverträglichkeit" (urban compatibility) of harm reduction measures was introduced as an important additional element (Kübler, 2001).

\section{An observational description of coalition building processes in the city of Zurich and beyond}

The following summarises the main challenges for a change in drug policy orientation, the change actors and their initiatives, the sequence of official reactions and the interactions between processes at the national and the local level.

The main challenges were an enormous increase in the incidence and prevalence of heroin injecting, in HIV infections among injectors, in overdose mortality and in drug-related delinquency. The most visible and shocking challenge were large open drug scenes ("needle parks"), with thousands of visitors (drug users, drug sellers, run-away adolescents and other people living on the margins) every day and with growing violence and misery.

The interpretation of the facts is a different issue. For many decades, all forms of substance use and abuse have been quite prominent in the general population, 
indicating - together with high suicide rates - a remarkable deficit in coming to terms with changing conditions for a satisfactory life. The early and outstanding HIV epidemic highest prevalence rates in Europe for many years - may be understood on the basis of the high overseas mobility of professionals. Illegal drug use was at first one form of youth protest against a conservative "establishment"; while most users learned quickly how to contain consumption and avoid negative consequences, others with severe social and psychological deficits were not met with adequate preventive and therapeutic measures. The massive open drug scenes in needle-parks were a result of repeated failure in dissolving drug scenes in more vulnerable residential or business areas; instead of chasing them around, police profited from observing and controlling criminal activities in a central location.

Change actors and their initiatives: the most diverse organisations and persons started to react, at first without a shared action plan, mostly along a strategy to avoid specific negative aspects, which in the course of action was labelled "harm reduction". The Medical Association recommended the provision of sterile syringes and needles, a coalition of infection specialists and the Red Cross organised blood testing and Hepatitis B immunisation right in needle park, ad hoc groups of concerned citizens and parents offered meals, a medical emergency team intervened in innumerable overdose cases, and medical, social and psychiatric support was provided in easily accessible drop-in centres. A specialised NGO for risk-free use of drugs was set up and opened a lowthreshold methadone clinic, without obligatory counselling and urine controls, but with visual intake control to avoid diversion and overdose. In 1988, a "Drogen Charta" was set up and published by a heterogeneous coalition of politicians, professionals, academics and NGO's. These initiatives have been well documented and described (Kübler, 2001; Grob, 2010; Uchtenhagen, 2010). During the entire process, print media as well as television reported frequently and mostly in favour of the innovations.

Official reactions: on the basis of the existing Federal Narcotic Law, reactions were at first decidedly repressive, but not coordinated between the national, cantonal and municipal levels. Psychiatric hospitals were not prepared to provide adequate care for drug-related acute and chronic conditions and discharged all patients engaging in drug use. Provision of syringes and needles was strictly prohibited and police was charged with confiscating used and unused ones. After initial rejection, low-threshold methadone prescribing was tolerated, as well as injection rooms and continued use in shelters. The Social Department in the City Administration changed from a repressive attitude against rebellious and drug using youth to an active policy of supporting measures to prevent health and social deterioration of users. The City Government became an active promoter of prescribing heroin to chronic heroin users; this initiative was taken up by the Federal Expert Committee on Drugs and finally by Federal Government, in the framework of the national 4-pillar drug policy of 1991. Harm reduction approaches were considered to be admissible within the framework of national legislation and international conventions by specially mandated law experts.

Interactions were most prominent between the various levels and sectors. The Zurich City Administration, together with representatives from other cities, proposed a new policy to Federal Government, including harm reduction as an essential element besides prevention, treatment and law enforcement. Three main political parties formed a shared platform at national level, in support of such a new policy. National professional associations reinforced action at the local level. Groups of concerned citizens also provided support, with the aim to reduce the nuisance of public drug use and drug scenes.

Opposition against the new policy trend and its main innovative element - harm reduction measures - was also widespread in various sectors, preferring a repressive law and order policy, mainly on the right-wing political spectrum as well as in conservative circles of doctors and psychologists, but also among professionals engaged in abstinence-only treatment services. On the other side, opposition was raised against the concept of a well-balanced policy, arguing for a legalisation of all drugs, in a belief that drug-related problems mainly stem from prohibition.

Sustainability of change was greatly supported by monitoring and evaluating the new policy and its innovations in prevention, treatment, harm reduction and law enforcement. This was a major provision in the 1991 policy paper and served three purposes: to recognise "what works" and needs for improvements, to provide an evidence base for political and public acceptance (nationally and internationally), and to give the Federal Office of Health a powerful position as commissioner, funding agency and coordinator of relevant research.

Positive outcomes in many local and some national referenda documented the growing acceptance for this balanced approach, culminating in the successful revision of Swiss narcotic law (with the inclusion of the 4-pillar policy) in 2008. After initial critical reactions from neighbouring countries and UN agencies, international acceptance was also growing and culminated in the adoption of harm reduction as an essential component of a balanced drug policy in the EU drugs strategy and action plans (EU, 2008).

\section{AN ATTEMPT AT PROCESS ANALYSIS OF COALITION BUILDING}

The change process described above evolved within less than a decade. It was not prepared, not driven by a readymade concept of a new policy or action plan. Nor was it based on a consistent concept of an open society fostering experimentation and innovation. It was rather driven by the unacceptable realities clashing with the cherished selfimage of professionals in the health and social sector of being competent and efficient in meeting new demands and also with the cherished self-image of a well-organised prosperous society. What was the unacceptable reality? 
Letting young people en masse ruin their life and future, letting them demonstrate their misery and letting them die in the very heart of the city, a few steps from the worldfamous Bahnhofstrasse and its international clientèle. This was the basis for concrete, bottom-up action at the front, as well as for re-thinking the policy concept.

Can some of the above-mentioned theories help us to better understand what happened?

The Actor-Network Theory certainly applies, on the basis of including non-human factors, in this case the excessive drug markets and the excessive HIV epidemic. As well, the hypotheses of Serduelt are confirmed. On the other side, the Advocacy Coalition Framework Theory as applied by Kübler allows to describe the competition between the "innovators" and the opposition, and it also helps to understand the interaction of both these networks in shaping the innovations in order to having less unintended negative effects. Finally, the Societal Learning Theory shows the need how to stabilise the process of change in new structural systems as a secondary process.

What needs to be looked at in an additional effort and in more detail is how actors find together and what their shared interests are. In our case study, multiple coalitions emerged, against all expectations. What brought them together was more than an overriding idea or belief, namely a shared objective for action and a joint need for concerted action.

A prominent example was the abolition of the legal and practical prohibition of needle and syringe availability in Zurich: illegal action by doctors and services, handing out sterile injection equipment to drug injectors, was followed by repealing the order to police to confiscate and use syringes as evidence in criminal investigation, by the commander of city police after the high rates of HIV seropositivity had been made public. Health authorities and prosecution allowed access to injection equipment, and in 1986 a cantonal parliamentary decision legalised the needle and syringe distribution. It followed a mass distribution for free by NGOs and street workers, mostly financed from public funds. The common objective for action in this informal coalition was to reduce needle sharing among users and thereby blood borne infections. In the absence of a pre-conceived action plan, the elements of joint action had to be developed step by step and had to support each other.

On the other side, opposition against syringe availability argued that this would lead to an increase of injectors and injecting. The discrepancy of prohibiting the use of illicit drugs (according to Swiss narcotic law) and to allow the distribution of instruments for injecting illicit drugs thus undercuttig the credibility of the state, was an additional argument. However, there was no other common objective except making opposition, no credible answer how to curb the rapid progress of HIV seropositivity, and no other action than producing pamphlets, making speeches and lobbying. This was in complete contrast to the "coalition for change" and may explain why opposition dwindled (it was not defeated) when it became more and more obvious that the new rules and practices worked well.
A completely different coalition was built up to strengthen not only public health, but public order as well, by improving support structures and treatment opportunities for injectors, on the countryside as well as in the city, and by reducing the attractiveness of the large urban drug scene (up to $80 \%$ of injectors interviewed in needle park came from outside). The Head of the Social Department of the City Administration called the heads of local authorities from all villages to visit needle park and to get a personal impression of it. The problem, formerly considered to be an urban problem only, was recognised as a general challenge. The Association of Local Mayors agreed to set up shelters and day programs in all parts of the Canton, the Cantonal Medical Association invited members to engage in office-based methadone maintenance treatment all over, and special continued training for doctors and pharmacists was implemented. The Cantonal Health Ministry agreed to subsidise the local support structures with $30 \%$ of eligible costs. At the same time, police law was re-interpreted : zero tolerance for public injecting and public trafficking, while private use and dealing without nuisance for others became more or less tolerated. The drug market withdrew from public places. Injectors could be arrested and brought to a special detention centre for a maximum of 24 hours; during this time they were medically examined and served, and transferred to hospital if needed. Injectors not living in the city were conducted by police to the local authorities where they belonged, and those had to pay for the transport (in order to prevent their sending back to the city). Low threshold clinics offering medical and psychiatric care, including methadone maintenance, were operating in all major regions of the canton. The City Administration set up low threshold contact centres, shelters and apartments for injectors and other marginal groups.

This process was not based on just one coalition, but on a system of sub-coalitions and networks, mostly of an informal nature, but some also formalised (e.g. agreements between Health Ministry and municipal authorities, or joint medical and police management of the detention centre). What kept this system together, was a range of interdependent shared objectives for action, namely:

-To dissolve needle park without chasing injectors again around the city and into the backyards (as it happened before when closing down the first large open drug scene).

-To prevent injectors from other parts of the Canton and other Cantons to come to the city to seek support and treatment.

-To reach out to injectors with psychiatric or somatic problems in order to improve their health status, and to reach out to homeless injectors by offering sheltered living.

-All in all, the objective was not to "solve" the drug problem, but to reduce its negative effects for injectors and the public at large.

Again, there was no ready-made action plan, nor can the range of activities be labelled to be harm reduction, or treatment, or law enforcement only. It was all of this, and the various activities had to complement each-other. In a 
next step,the general framework was provided by Federal Government proposing the national 4-pillar drug policy in 1991, a directive which again did not impose a special action plan, but exposed options for innovation, collaboration and evaluation, and invited creative answers to the existing or emerging problems.

\section{CONCLUSIONS AND FINAL REMARKS}

Theories on the role of coalitions and actor networks have much improved our understanding of how urgent social problems can be seen in a new light and tackled with a new strategy, and how these innovations may be stabilized in a new structural system. However, the very start of emerging coalitions and networks needs to be focused with specific hypotheses about shared objectives as a basis for joint action. The process analysis presented above demonstrates the usefulness of asking for the concrete objectives bringing actors together. A clear policy concept and a consistent action plan are not found to be at the start of coalition building, but rather an important step in the consolidation of what was a non-systematic beginning.

What started at local level and led to a new national policy was not a continued clash between two ideologies - harm reduction versus strict prohibition -, but was the beginning of a new thinking about how the various policy elements could successfully work together in the pursuit of a shared concrete objective. This included a shift to base political decisionmaking from an adherence to abstract principles ("a drugfree society") to an effort to evaluate activities and to provide evidence on their intended and unintended effects.

Two specific aspects of the Swiss example must be mentioned. Our society has a longstanding tradition of coalition-building whenever an urgent problem was not adequately met by politics. In the field ob substance abuse, a prominent case was the founding of women's associations for alcohol-free restaurants, in a time of excessive prevalence of alcohol related problems in early $20^{\text {th }}$ century. The other aspect is a rather new one: the relative tolerance of our local governments for civil disobedience by making syringes available and setting up the first injection rooms; instead of sanctioning they observed the effects and then tuned in. Both aspects may have contributed to an effective and finally well accepted policy change.

In recent years, coalitions emerged for an adequate urban drug policy, doing justice to the specific burdens of cities with illicit (and legal) drugs and promoting solutions tailored to the local needs (DCD, 2005; DCDII, 2008; Prague Declaration, 2010). This opens a perfect opportunity to study the relevant change processes in different societies and political systems. Both theory development and policy development could profit from such studies.

\section{REFERENCES}

Callon, M., Lascoumes, P. \& Barthe, Y. (2009). Acting in an Uncertain World. An Essay on Technical Democracy. Cambridge: MIT Press.
DCD (2005). Democracy, Cities and Drugs project 2005-2007 (www. democitydrug.org).

DCDII (2011). Democracy, Cities and Drugs project 2008-2011. (www. democitydrug.org).

EU (2008). Communication from the Commission to the European Parliament and the Council on an EU Drugs Action Plan for 2009-2012. COM (2008) 567/4. Brussels 18.9.2008.

Freeman, L. (2006). The Development of Social Network Analysis. Vancouver: Empirical Press.

Grob, P. (2010). Zürcher "Needle Park" Ein Stück Drogengeschichte und -politik 1968-2008 (The needle-park in Zurich. A lesson in drug history and -policy 1968-2008). Zürich: Chronos.

Kübler, D. (1999) Beyond nimbyism. Urban conflict resolution in Swiss drug policies, in U. Khan (ed.), Participation Beyond the Ballot Box. European Case Studies in State-Citizen Dialogue (pp. 43-64). London: UCL Press.

Kübler, D. (2000). Politique de la drogue dans les villes suisses entre ordre et santé. Analyse des conflits de mise en oeuvre, Paris: L'Harmattan.

Kübler, D. (2001). Understanding policy change with the advocacy coalition framework: an application to Swiss Drug Policy. Journal of European Public Policy, 8:623-641.

Latour, B. (2005). Reassembling the Social: An Introduction to ActorNetwork-Theory. Oxford: Oxford University Press.

Law, J. \& Hassard J. (eds) (1999). Actor Network Theory and After. Oxford: Blackwell.

May, C., Mair, F.S., Finch, T., MacFarlane, A., Dowrick, C., Treweek, S., Rapley, T., Ballini, L., et al. (2009). Development of a theory of implementation and integration: Normalization Process Theory. Implementation Science 4: 29.

Prague Declaration (2011). On the principles of effective urban drug policies. Presented and adopted at the Prague Conference on Urban Drug Policies in a Globalised World Sept 2010 (www. drugpolicy.com).

Rogers, E. M. (2003). Diffusion of innovations (5th ed.). New York, Free Press.

Sabatier, P.A. (1998). The advocacy coalition framework: revisions and relevance for Europe. Journal of European Public Policy 5: 98-130.

Serduelt, U. (2000). Politiknetzwerke in der städtischen Drogenpolitik von Bern, Chur, St. Gallen und Zürich (Policy networks for urban drug policies in Bern, Chur, St. Gallen and Zurich). PhD Thesis, University of Zurich.

Uchtenhagen, A. (2010). Heroin-assisted treatment in Switzerland: a case study in policy change. Addiction 105:29-37

Waddell, S. (2005). Societal learning and Change. Sheffield UK: Greenleaf Publishing.

Wejnert, B. (2002). Integrating Models of Diffusion of Innovations: A Conceptual Framework. Annual Review of Sociology (Annual Reviews) 28: 297-306.

WHO (2001) World Health Report 2001. Mental Health: New understanding, new hope. Geneva, World Health Organisation. 
